\title{
Nutritional and protein quality of dry Brazilian beans (Phaseolus vulgaris L.)
}

\author{
Amanda Alves REZENDE ${ }^{1 *}$, Maria Teresa Bertoldo PACHECO², Vera Sônia Nunes da SILVA², \\ Tânia Aparecida Pinto de Castro FERREIRA ${ }^{1}$
}

\begin{abstract}
Brazil is the world's largest producer of common beans (Phaseolus vulgaris L.), which are one of the most widely consumed grain legumes in the world. Seven improved genotypes of dry, coloured, Brazilian common beans were analysed for their nutritional (chemical composition, oligosaccharides, phenolic compounds and antioxidant capacity) and protein quality (amino acid profile, amino acid score, trypsin inhibitor activity and in vitro protein digestibility). The grain bean cultivars studied showed a high content of fibre, with some aromatic amino acids present at higher levels than the Food and Agriculture Organization reference protein. The dry beans had intermediate protein digestibility, ranging from $50.3 \%$ in the BRS Notável cultivar to $66.9 \%$ in the Jalo Precoce cultivar. The studied dry beans contained anti-nutritional and flatulence factors, such as trypsin inhibitors and oligosaccharides. However, total phenolic compounds and antioxidant activity were high. Improved grain beans have important nutritional characteristics that need to be preserved, and some negative, anti-nutritional characteristics. The results presented in this study can be used to assist the identification of appropriate processing techniques that maintain the positive features of dry beans and eliminate their negative attributes.
\end{abstract}

Keywords: antioxidant capacity; chemical composition; in vitro protein digestibility; total phenolic compounds.

Practical Application: Our results can be applied in development of products to maintain a better profile of amino acids, in recommended of daily intake, in menu planning and in the separation of amino acids as an isolated nutrient.

\section{Introduction}

Common grain beans (Phaseolus vulgaris L.) have been recognised as a staple and low-cost protein source, consumed in both several under-developed countries, where protein malnutrition is widely prevalent, as well as in developing countries where protein malnutrition is low, such as Brazil (Drewnowski, 2010; Food and Agriculture Organization, 2013; Sathe, 2002; Shimelis \& Rakshit, 2007).

Beans are rich in protein, carbohydrate, dietary fibre, and are a good source of antioxidants, as well as vitamins and minerals (Campos-Veja et al., 2010; Luthria \& Pastor-Corrales, 2006). Animal proteins are better assimilated than vegetable proteins because plant proteins are deficient in sulphur amino acids (methionine and cysteine), and tryptophan. Therefore, a diet that combines protein-containing foods with complementary cereal amino acids is important to gain the complete amino acid pool (Karababa, 2006; Melo et al., 2012).

Beans contain many bioactive substances that play important physiological roles in vivo, including, protein digestibility enzyme inhibitors, others types of enzyme inhibitors and fermentablenon-digestible oligosaccharides (Campos-Veja et al., 2010; Drewnowski, 2010; Food and Agriculture Organization, 2013; Ranilla et al., 2007). There is room for improvement the bioactive properties of unprocessed dry bean and thus a need to examine new cultivars (cvs.).
The beans researched in this study are cvs. developed by the Brazilian Agricultural Research Corporation (Empresa Brasileira de Pesquisa Agropecuária, 2013) breeding program. These cvs. present one or more of the following characteristics: suitability to direct mechanical harvesting, high productivity and yield, disease resistance and early maturity, besides desirable culinary and nutritional characteristics, such as ease of cooking, good palatability, soft texture seed coat and improved protein content (Melo et al., 2012). Furthermore, these beans studied are widely consumed in Brazil and the cvs. show market acceptable virtues regarding shape, size, colour and brightness.

\section{Materials and methods}

\subsection{Samples}

The beans (Figure 1) were provided by Empresa Brasileira de Pesquisa Agropecuária Rice and Beans, located in Santo Antônio de Goiás, Brazil (16³0’23.62”S and 49.17’.00.75”W). and harvested in the winter of 2013. The local climate is classified as warm and semi-humid with a well-defined dry season, from May to September, and an annual average temperature of $23.2^{\circ} \mathrm{C}$, with minimum and maximum averages of 17.9 and $29.8^{\circ} \mathrm{C}$, respectively. 

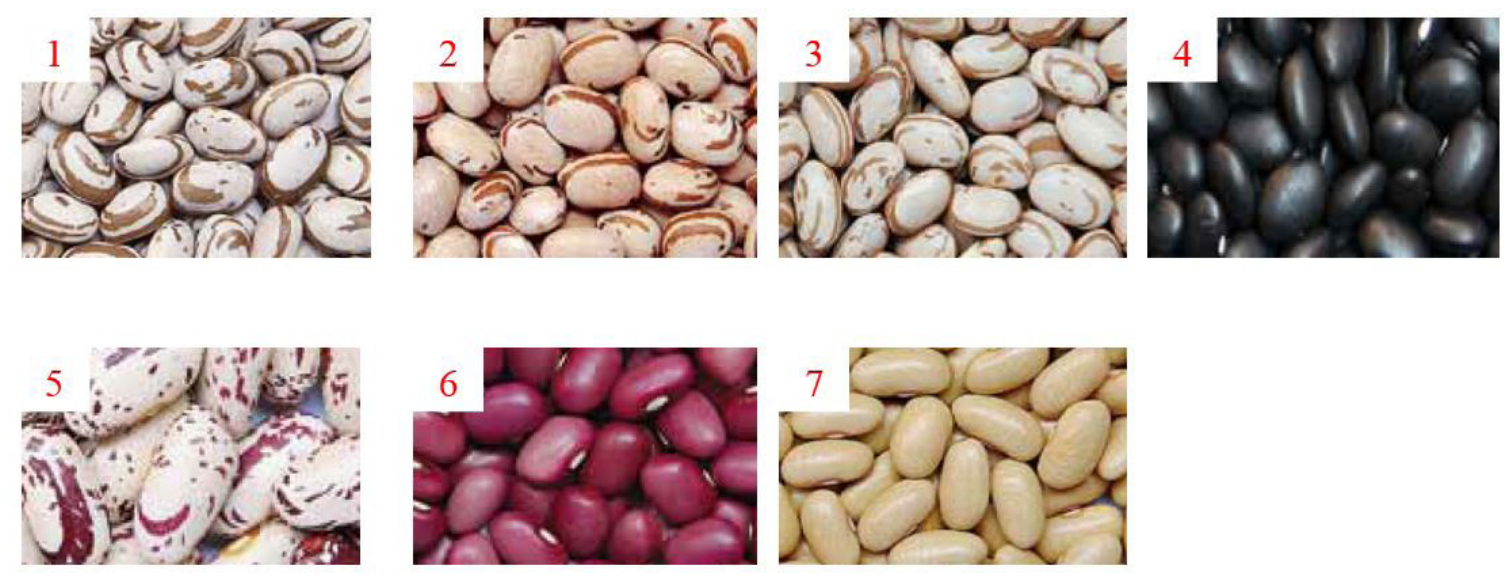

Figure 1. Grain Brazilian bean (Phaseolus vulgaris L.) improved genotypes. (1) BRS Ametista; (2) BRS Notável; and (3) Pérola (light beige beans with brown stripe); (4) BRS Esplendor (black); (5) BRS Executivo (beige with streaks and dark red scores); (6) BRS Pitanga (light purple); (7) Jalo Precoce (yellow).

\subsection{Mass determination}

Mass (Karababa, 2006) was determined by weighing 100 randomly chosen beans, using an analytical balance with a precision of $\pm 0.1 \mathrm{~g}$. This procedure was performed in triplicate.

\subsection{Sample preparation}

Broken and damaged beans, as well as foreign materials, were removed. Then, the samples were ground in a mill to obtain a fine and homogeneous powder (60 mesh) using an Ultra Centrifugal Mill (Retsch ZM200, Haan, Germany), and maintained at $-18^{\circ} \mathrm{C}$ until analysis.

\subsection{Nutritional quality}

Moisture content was determined by oven drying at $105{ }^{\circ} \mathrm{C}$ to constant weight (Instituto Adolfo Lutz, 2008). The Bligh \& Dyer (1959) method determined the total lipids. Total dietary fibre was quantified according to Horwitz \& Latimer (2010). Total carbohydrates were calculated by summing the values of starch, total dietary fibre and oligosaccharides. The oligosaccharide raffinose family contents were performed as described by Cicek (2001). For mineral content determination, samples were incinerated using a heater plate and then placed in a muffle at $550{ }^{\circ} \mathrm{C}$ to constant weight (Horwitz \& Latimer, 2010). Starch content was obtained according to Diemair (1963).

Total phenolic compounds (TPC) were determined using the Folin-Ciocalteu method. The results were expressed as milligram gallic acid equivalents per gram of sample (mg GAE. ${ }^{-1}$ sample) (Singleton \& Rossi, 1965). Antioxidant activity was assessed using the stable free radical, 2,2-diphenyl-1-picrylhydrazyl (DPPH), according to Brand-Williams et al. (1995).

\subsection{Protein quality}

Protein content was determined using the micro-Kjeldahl method and a conversion factor of 6.25 (Horwitz \& Latimer, 2010). The total amino acids were verified as described by White et al. (1986) and Hagen et al. (1989). The separation and identification of phenylthiocarbamide-amino acid (PTC-AA) derivatives were performed using a high-resolution liquid chromatograph (Shimadzu Corporation, Tokyo, Japan) equipped with a Phenomenex-Luna C18 reverse phase column $(250 \times 4.6 \mathrm{~mm}, 5 \mu \mathrm{m}$; Phenomenex Inc., Torrance, USA). The mobile phase consisted of an acetate buffer pH6.4 and acetonitrile solution at 40\%.

Essential amino acids (EAA) in the samples were evaluated by amino acid score (AAS), which was based on the recommended EAA levels established by the World Health Organization (2007) of 3-10-year-old children.

The in vitro protein digestibility $\left({ }_{\mathrm{IV}} \mathrm{PD}\right)$ was determined according to the method described by Akeson \& Stahmann (1964). This involved sample digestion with pepsin and pancreatic enzymes, followed by precipitation of the undigested proteins in a solution of sodium azide $0.01 \%$, and their quantification by micro-Kjeldahl (Horwitz \& Latimer, 2010). The results were expressed as a percentage of the total protein. The trypsin inhibitor activity (TIA) was determined by an enzymatic method using a solution of D-benzoyl p-nitroanilide L-arginine as substrate and expressed as trypsin inhibitor units (TIU) per $g$ of protein (Rackis et al., 1974).

\subsection{Statistical analysis}

The results were expressed as the mean \pm standard deviation. The comparison between cvs. was verified by analysis of variance followed by a comparison of means by Tukey's test. Differences were considered significant when $\mathrm{p}<0.05$. Statistical analyses were performed using R 3.1.0 software (R Development Core Team, 2012). Pearson's correlation was performed between the TPC and antioxidant activity and between the in vitro protein digestibility and trypsin inhibitor activity in the dry beans.

\section{Results}

\subsection{Beans}

Many varieties, including cv., botanical taxon, commercial group and color, of dry beans, are consumed by the world population, and some of them were studied in the present study. The common bean Brazilian cvs. are separated in to 
commercial groups according to the type of grain, and the most consumed ones are the carioca (79\%) and black group (17\%) (Melo et al., 2012). The beans of this study belong to the carioca (BRS Ametista, BRS Notável and Pérola), black (BRS Esplendor) and special commercial groups (BRS Pitanga, BRS Executivo and Jalo Precoce) (Empresa Brasileira de Pesquisa Agropecuária, 2013). As noted by the mass of the beans, the commercial groups most consumed by Brazilians are those of smaller size (carioca and black).

There were significant differences $(\mathrm{p}<0.05)$ in the mass among all cvs. The BRS Executivo cv. had the largest mass, while BRS Esplendor cv. had the lowest (Table 1).

\subsection{Nutritional quality}

For all cvs. studied, significant differences $(\mathrm{p}<0.05)$ were observed in most of the nutrient contents (Table 2). The total of lipid, carbohydrate and oligosaccharide contents (raffinose and stachyose) were statistically similar $(\mathrm{p}<0.05)$ among the $\mathrm{cv}$. In accordance with their classification as a rich source of fibre (Wu et al., 2004), the total fibre contents of the beans ranged from $21 \mathrm{~g} .100 \mathrm{~g}^{-1}$ (Pérola) to $24 \mathrm{~g} .100 \mathrm{~g}^{-1}$ (BRS Ametista).

All the bean cvs. studied showed a high TPC ( $>2$ mg GAE.g $\left.{ }^{-1}\right)$, with the Jalo Precoce cv. revealing the highest TPC at 9 mg EAG. ${ }^{-1}$ (Table 3). This cv. also had the highest antioxidant activity $(63 \mu \mathrm{mol}$ Trolox $\left.\mathrm{g}^{-1}\right)$. A positive and significant correlation $(\mathrm{r}=0,988$, $\mathrm{p}<0.05$ ) between the TPC and antioxidant activity was evident.

\subsection{Protein quality}

The protein values ranged 19 to $23 \mathrm{~g} .100 \mathrm{~g}^{-1}$. In the cvs. studied, glutamic acid and aspartic acid were the predominant non-essential amino acids (NEAA), while the aromatic amino acids, phenylalanine + tyrosine, followed by lysine and leucine were the predominant EAA (Table 4). The lysine content varied from 93 to $104 \mathrm{mg} / \mathrm{g}$ protein (BRS Esplendor and BRS Ametista, respectively), while the leucine content ranged from 72 to $78 \mathrm{mg} \cdot \mathrm{g}^{-1}$ protein (BRS Esplendor and BRS Notável, respectively).

Almost all the eight EAA could satisfy the reference values needs (Table 5), ranging the EAS from 1.2 to 2.6, except for the deficient amino acids, namely cysteine and methionine (0.8).

For both the ${ }_{\text {IV }} \mathrm{PD}$ and TIA analyses, the results displayed a significant difference between cvs. $(\mathrm{p}<0.05)$ (Table 6).

\section{Discussion}

\subsection{Beans}

The common bean Brazilian cvs. are separated in to commercial groups according to the type of grain, and the most consumed ones are the carioca (79\%) and black group (17\%). The beans of this study belong to the carioca (BRS Ametista, BRS Notável and Pérola), black (BRS Esplendor) and special commercial groups (BRS Pitanga, BRS Executivo and Jalo Precoce) (Empresa Brasileira de Pesquisa Agropecuária, 2013). As noted by the mass of the beans, the commercial groups most consumed by Brazilians are those of smaller size (carioca and black).
Table 1. Average mass of Brazilian bean cultivars.

\begin{tabular}{ccc}
\hline Cultivar & $\begin{array}{c}\text { Commercial } \\
\text { classification }\end{array}$ & $\begin{array}{c}\text { Mean mass } \\
\text { (g/ 100 beans) }\end{array}$ \\
\hline BRS Ametista & Carioca & $32 \pm 0^{\mathrm{c}}$ \\
BRS Notável & Carioca & $26 \pm 0^{\mathrm{d}}$ \\
Pérola & Carioca & $23 \pm 0^{\mathrm{e}}$ \\
BRS Esplendor & Black & $17 \pm 0^{\mathrm{g}}$ \\
BRS Executivo & Special & $65 \pm 1^{\mathrm{a}}$ \\
BRS Pitanga & Special & $20 \pm 0^{\mathrm{f}}$ \\
Jalo Precoce & Special & $36 \pm 0^{\mathrm{b}}$ \\
\hline
\end{tabular}

Results are the average of three independent experiments \pm SEM. Different letters among samples indicate significant differences by Tukey's test $(\mathrm{p}<0.05)$.

Table 2. Chemical composition of Brazilian bean cultivars of improved genotypes.

\begin{tabular}{cccccc}
\hline \multirow{2}{*}{ Cultivar } & \multicolumn{5}{c}{ Chemical composition (g.100 g $\mathrm{g}^{-1}$ sample) } \\
\cline { 2 - 6 } & Protein & Lipid & Ash & Carbohydrate* & Moisture \\
\hline 1-AM & $20 \pm 0^{\mathrm{d}}$ & $2 \pm 0^{\mathrm{a}}$ & $4 \pm 0^{\mathrm{a}}$ & $64 \pm 1^{\mathrm{a}}$ & $12 \pm 0^{\mathrm{a}}$ \\
2-NO & $22 \pm 1^{\mathrm{bc}}$ & $2 \pm 0^{\mathrm{a}}$ & $4 \pm 0^{\mathrm{a}}$ & $65 \pm 0^{\mathrm{a}}$ & $12 \pm 0^{\mathrm{a}}$ \\
3-PE & $21 \pm 0^{\mathrm{cd}}$ & $2 \pm 0^{\mathrm{a}}$ & $4 \pm 0^{\mathrm{a}}$ & $66 \pm 1^{\mathrm{a}}$ & $10 \pm 0^{\mathrm{c}}$ \\
4-ES & $19 \pm 0^{\mathrm{e}}$ & $2 \pm 0^{\mathrm{a}}$ & $4 \pm 0^{\mathrm{a}}$ & $65 \pm 1^{\mathrm{a}}$ & $10 \pm 0^{\mathrm{c}}$ \\
5-PI & $19 \pm 0^{\mathrm{e}}$ & $2 \pm 0^{\mathrm{a}}$ & $4 \pm 0^{\mathrm{a}}$ & $65 \pm 0^{\mathrm{a}}$ & $10 \pm 0^{\mathrm{c}}$ \\
6-EX & $23 \pm 0^{\mathrm{a}}$ & $2 \pm 0^{\mathrm{a}}$ & $4 \pm 0^{\mathrm{a}}$ & $64 \pm 0^{\mathrm{a}}$ & $12 \pm 0^{\mathrm{a}}$ \\
7-JP & $22 \pm 0^{\mathrm{b}}$ & $2 \pm 0^{\mathrm{a}}$ & $3 \pm 0^{\mathrm{b}}$ & $64 \pm 1^{\mathrm{a}}$ & $11 \pm 0^{\mathrm{b}}$ \\
\hline \multicolumn{5}{c}{ Carbohydrates total (g.100 g $^{-1}$ sample) } \\
\cline { 2 - 5 } 1-BRS Ametista & $36 \pm 1^{\mathrm{d}}$ & $4 \pm 0^{\mathrm{a}}$ & $24 \pm 0^{\mathrm{a}}$ \\
2-BRS Notável & $38 \pm 0^{\mathrm{cd}}$ & $4 \pm 0^{\mathrm{a}}$ & $23 \pm 0^{\mathrm{ab}}$ \\
3-Pérola & $42 \pm 1^{\mathrm{a}}$ & $3 \pm 0^{\mathrm{b}}$ & $21 \pm 0^{\mathrm{d}}$ \\
4-BRS Esplendor & $40 \pm 0^{\mathrm{ab}}$ & $3 \pm 0^{\mathrm{b}}$ & $22 \pm 0^{\mathrm{cd}}$ \\
5-BRS Executivo & $39 \pm 0^{\mathrm{bc}}$ & $3 \pm 0^{\mathrm{b}}$ & $23 \pm 0^{\mathrm{ab}}$ \\
6-BRS Pitanga & $39 \pm 0^{\mathrm{bc}}$ & $4 \pm 0^{\mathrm{a}}$ & $21 \pm 0^{\mathrm{d}}$ \\
7-Jalo Precoce & $36 \pm 0^{\mathrm{d}}$ & $4 \pm 0^{\mathrm{a}}$ & $23 \pm 0^{\mathrm{ab}}$ \\
\hline
\end{tabular}

Results are the average of three independent experiments \pm SEM. AM $=$ BRS Ametista, $\mathrm{NO}=\mathrm{BRS}$ Notável, $\mathrm{PE}=$ Pérola, $\mathrm{ES}=\mathrm{BRS}$ Esplendor, $\mathrm{PI}=\mathrm{BRS}$ Pitanga, $\mathrm{EX}=\mathrm{BRS}$ Executivo, JP = Jalo Precoce. Different letters among samples indicate significant differences by Tukey's test $(\mathrm{p}<0.05)$; ${ }^{*}$ Determined as the total starch + oligosaccharide + dietary fibre. Nitrogen to protein conversion factor: 6.25 .

Table 3. Total phenolic compounds (mg GAE $\mathrm{g}^{-1}$ ) and antioxidant activity measured by DPPH ( $\mu$ mol Trolox $\left.\mathrm{g}^{-1}\right)$ of Brazilian bean cultivars of improved genotypes.

\begin{tabular}{lcc}
\hline \multicolumn{1}{c}{ Cultivar } & $\begin{array}{c}\text { Total phenolic compounds } \\
\left(\mathrm{mg} \mathrm{GAE}^{\star} \mathrm{g}^{-1}\right)\end{array}$ & $\begin{array}{c}\text { Antioxidant activity } \\
(\mu \mathrm{mol} \mathrm{Trolox} \mathrm{g})^{-1}\end{array}$ \\
\hline 1-BRS Ametista & $8 \pm 0^{\mathrm{b}}$ & $59 \pm 0^{\mathrm{bc}}$ \\
2-BRS Notável & $8 \pm 0^{\mathrm{b}}$ & $58 \pm 2^{\mathrm{c}}$ \\
3-Pérola & $5 \pm 0^{\mathrm{c}}$ & $35 \pm 1^{\mathrm{e}}$ \\
4-BRS Esplendor & $4 \pm 0^{\mathrm{cd}}$ & $38 \pm 0^{\mathrm{d}}$ \\
5-BRS Executivo & $8 \pm 0^{\mathrm{b}}$ & $61 \pm 0^{\mathrm{ab}}$ \\
6-BRS Pitanga & $4 \pm 0^{\mathrm{d}}$ & $35 \pm 2^{\mathrm{e}}$ \\
7-Jalo Precoce & $9 \pm 0^{\mathrm{a}}$ & $63 \pm 2^{\mathrm{a}}$ \\
\hline
\end{tabular}

Results are the average of three independent experiments \pm SEM. Different letters among samples indicate significant differences by Tukey's test $(\mathrm{p}<0.05) ;{ }^{*}$ Gallic acid equivalent. 
Table 4. Essential and non-essential amino acid composition of Brazilian bean cultivars of improved genotypes.

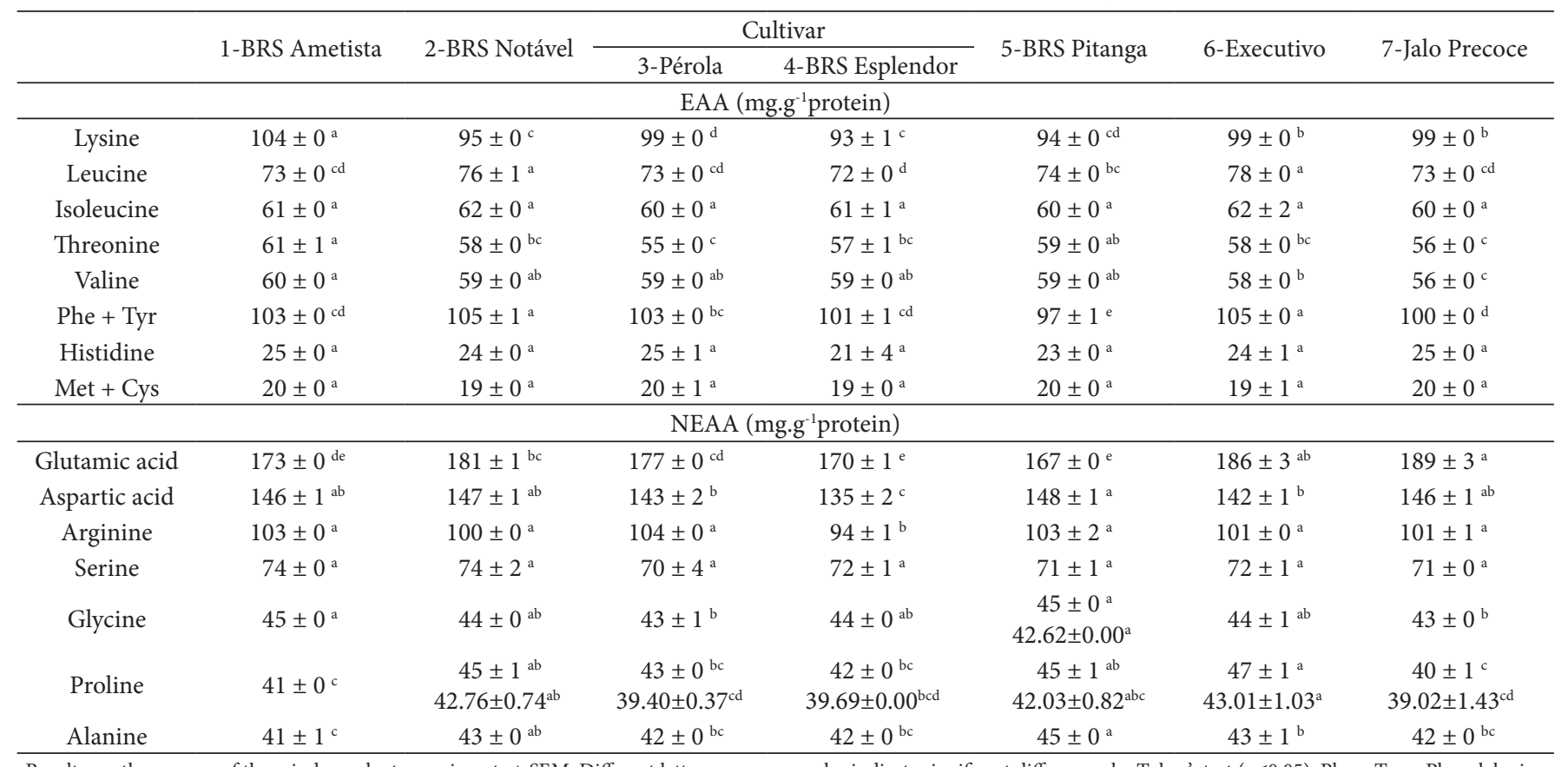

Results are the average of three independent experiments \pm SEM. Different letters among samples indicate significant differences by Tukey's test ( $\leq 0.05$ ). Phe + Tyr $=$ Phenylalanine

+ Tyrosine. Met + Cys $=$ Methionine + Cysteine. Tryptophan $=$ Not determined.

Table 5. Amino acids score for the proteins of Brazilian bean cultivars of improved genotypes.

\begin{tabular}{|c|c|c|c|c|c|c|c|}
\hline $\begin{array}{c}\text { Amino } \\
\text { acid }\end{array}$ & BRS Ametista & BRS Notável & Pérola & $\begin{array}{c}\text { Cultivar } \\
\text { BRS Esplendor } \\
\end{array}$ & BRS Pitanga & Executivo & Jalo Precoce \\
\hline Lys & 2.2 & 2 & 2.1 & 1.9 & 2 & 2.1 & 2.1 \\
\hline Met + Cys & 0.8 & 0.8 & 0.8 & 0.8 & 0.8 & 0.8 & 0.8 \\
\hline Thr & 2.4 & 2.3 & 2.2 & 2.3 & 2.3 & 2.3 & 2.2 \\
\hline Ile & 2 & 2.0 & 1.9 & 2 & 1.9 & 2 & 2 \\
\hline Leu & 1.2 & 1.2 & 1.2 & 1.2 & 1.2 & 1.2 & 1.2 \\
\hline His & 1.5 & 1.5 & 1.5 & 1.3 & 1.5 & 1.5 & 1.6 \\
\hline
\end{tabular}

Lys $=$ Lysine, Met + Cys $=$ Methionine + Cysteine. The $=$ Threonine, Ile $=$ Isoleucine, Leu $=$ Leucine, Val= Valine, Phe + Tyr $=$ Phenylalanine + Tyrosine, His $=$ Histidine. Based on FAO/WHO reference of 3-10-year-old children (World Health Organization, 2007). The limited amino acids are in bold.

Table 6. Protein digestibility by in vitro enzymatic digestion, and trypsin inhibitory activity in Brazilian bean cultivars of improved genotypes.

\begin{tabular}{lcc}
\hline \multicolumn{1}{c}{ Cultivar } & $\begin{array}{c}\text { In vitro protein } \\
\text { digestibility }(\%)\end{array}$ & $\begin{array}{c}\text { Trypsin inhibitory } \\
\text { units } \\
\text { (TIU/gprotein) }\end{array}$ \\
\hline 1-BRS Ametista & $54 \pm 2^{\text {cd }}$ & $33 \pm 0^{\mathrm{b}}$ \\
2-BRS Notável & $50 \pm 4^{\mathrm{d}}$ & $29 \pm 0^{\mathrm{c}}$ \\
3-Pérola & $56 \pm 1^{\mathrm{bc}}$ & $45 \pm 1^{\mathrm{a}}$ \\
4-BRS Esplendor & $54 \pm 2^{\mathrm{bcd}}$ & $33 \pm 0^{\mathrm{b}}$ \\
5-BRS Executivo & $60 \pm 2^{\mathrm{b}}$ & $27 \pm 0^{\mathrm{d}}$ \\
6-BRS Pitanga & $50 \pm 2^{\text {cd }}$ & $21 \pm 1^{\mathrm{f}}$ \\
7-Jalo Precoce & $67 \pm 0^{\mathrm{a}}$ & $25 \pm 0^{\mathrm{e}}$ \\
\hline Results are the average of three independent experiments $\pm \mathrm{SEM}$. Different letters \\
among samples indicate significant differences by Tukey's test (p<0.05). TIU: Trypsin \\
units inhibited, where $1 \mathrm{TU}$ is defined as 0.01 absorbance at $410 \mathrm{~nm}$, under the assay \\
conditions of the method (pH 8.2 at $37^{\circ} \mathrm{C}$ with $10 \mathrm{~mL}$ assay volume and bovine trypsin).
\end{tabular}

\subsection{Nutritional quality}

The cvs. studied were from a Brazilian breeding program aimed to favour the aspects of agriculture, productivity and nutritional value. The chemical and nutritional composition of the dry beans were different among the cvs. A similar phenomenon was also observed in the beans reported by Costa et al. (2006) and Shimelis \& Rakshit (2005). This difference could be solely due to genotypic differences among the cvs, once because the crops were from the same agronomic region and period (Costa et al., 2006; Ribeiro et al., 2007).

Among the total carbohydrates, this study discriminated the starches (reducing and non-reducing), oligosaccharides and dietary fibre. The carbohydrate and the total oligosaccharide contents found were equal among the cvs. and similar to previously 
studied improved genotype Brazilian bean cvs. (Pontal and IAC Eté) (60 to 66 g.100 g-1) (Costa et al., 2006; López et al., 2013) and white Canadian beans (Linsberger-Martin et al., 2013).

In recent years, coloured beans have attracted much attention due to the various health benefits associated with their consumption. Many studies showed their beneficial effects on blood cholesterol, glucose and insulin levels, in addition to prevention of various cancers, such as gastrointestinal, breast and prostate. These properties have been attributed to the unique nutritional composition of the bean that is rich in fibre and phenolic compounds, and low in total fat and saturated fat (Boateng et al., 2008; Karababa, 2006; Marathe et al., 2011; Ranilla et al., 2010; Sievenpiper et al., 2009; Thompson et al., 2008; Wu et al., 2004; Xu \& Chang, 2009). The Chinese and Brazilian beans have a similarly high content of dietary fibre (Wu et al., 2004; Costa et al., 2006).

All the bean cvs. studied revealed a high TPC. Similar TPC values were reported in a study of 10 classes and 15 varieties of beans commonly consumed in the USA (Luthria $\&$ Pastor-Corrales,2006). Other studies on Brazilian and Italian beans cvs. also observed high TPC and antioxidant capacities (Estrada-Girón et al., 2005; Han et al., 2007).

\subsection{Protein quality}

All the bean cvs. in this research presented high protein contents. Legumes, which are rich in lysine but poor in sulphur amino acids, like methionine and cysteine, can be mixed with cereals to improve the amino acid pattern of both raw materials (Sarwar, 1997; Toledo et al., 2013). For instance, beans and rice are a typical combination consumed in Brazil.

Protein digestibility varies with the cv. The literature reports that light-coloured grains have higher digestibility than colourful ones, which is associated with the content and nature of the tannins in the peel of coloured varieties (Linsberger-Martin et al., 2013; Sarwar, 1997).

According to Sarwar (1997), to validate the nutritional value of protein it is necessary to take into account the digestibility associated with the same amino acid profile as close as possible to the needs established for humans (World Health Organization, 2007). Nineteen Brazilian bean cvs. from the south of the country showed higher levels of leucine than lysine (Ribeiro et al., 2007). However, as observed in various legume crops (Lisiewska et al., 2007; Pedrosa et al., 2015; Slupski, 2010), they contained the eight essential amino acids but were deficient in methionine and cysteine (Ribeiro et al., 2007).

The current study found the Jalo Precoce cv. (67\%), a yellow bean, had the highest ${ }_{I V} P D$. Comparatively higher ${ }_{I V}$ PD values, up to $81 \%$, were observed in eight African bean cvs. (Shimelis \& Rakshit, 2007).

The trypsin inhibitor is considered an anti-nutritional factor present in various leguminous plants, including dry beans (Park et al., 2010). Studies show that this inhibitor adversely affects the digestibility of protein and amino acids, and hence, the protein quality (Drewnowski, 2010; Park et al., 2010; Shimelis, \& Rakshit, 2005). In this study, the BRS Pitanga cv. showed the lowest trypsin inhibitor content, and also had a low ${ }_{I V} \mathrm{PD}$, However, there was no correlation between the TIA and ${ }_{I V} \mathrm{PD}$ $(\mathrm{r}=-0.2533, \mathrm{p}<0.05)$. Probably other matrix components, such as phytate-protein complexes and high dietary fibre levels, or the chemical structure of the protein interfered more directly with this parameter.

\section{Conclusions}

Among the cvs. studied, BRS Ametista, BRS Notável and Jalo Precoce showed the highest levels of dietary fibre, while Executive cv. revealed the highest protein content. All the cvs. studied serve as an excellent dietary source of natural antioxidants and the Jalo Precoce cv. had the highest antioxidant activity. The minimal amino acids score was about 0,8 and related to the methionine and cysteine amino acids. From a nutritional perspective, the results presented will help researchers and consumers to select the best coloured Brazilian dry bean cvs. regarding their nutritive and bioactive properties. Combining bean cvs. that are characterised by a high protein quality, high dietary fibre content and antioxidant capacity, and low presence of anti-nutritional components, including oligosaccharides and trypsin inhibitor, with a food processing technique that complements their health benefits is important to improve their final quality.

\section{References}

Akeson, W. R., \& Stahmann, M. A. (1964). A pepsin pancreatin digest index of protein quality evaluation. The Journal of Nutrition, 83(3), 257-261. PMid:14191426.

Bligh, E. G., \& Dyer, W. J. (1959). A rapid method of total lipid extraction and purification. Canadian Journal of Biochemistry and Physiology, 37(8), 911-917. PMid:13671378. http://dx.doi.org/10.1139/059-099.

Boateng, J., Verghese, M., Walker, L. T., \& Ogutu, S. (2008). Effect of processing on antioxidant contents in selected dry beans (Phaseolus spp. L.). Lebensmittel-Wissenschaft + Technologie, 41(9), 1541-1547. http://dx.doi.org/10.1016/j.lwt.2007.11.025.

Brand-Williams, W., Cuvelier, M. E., \& Berset, C. (1995). Use of a free radical method to evaluate antioxidant activity. LebensmittelWissenschaft + Technologie, 28(1), 25-30. http://dx.doi.org/10.1016/ S0023-6438(95)80008-5.

Campos-Veja, R., Loarca-Pina, G., \& Oomah, B. D. (2010). Minor components of pulses and their potential impact on human health. Food Research International, 43(2), 461-482. http://dx.doi. org/10.1016/j.foodres.2009.09.004.

Cicek, M. (2001). Genetic marker analysis of three major carbohydrates in soybean (Ph.D. thesis). Faculty of the Virginia Polytechnic Institute and State University, Blacksburg.

Costa, G. E. A., Queiroz-Monici, K. S., Reis, S. M. P. M., \& Oliveira, A. C. (2006). Chemical composition, dietary fibre and resistant starch contents of raw and cooked pea, common bean, chickpea and lentil legumes. Food Chemistry, 94(3), 327-330. http://dx.doi. org/10.1016/j.foodchem.2004.11.020.

Diemair, W. (1963). Laboratoriumsbuch fur Lebensmittel Chemiker (8th ed.). Dresden: Verlag von Theodor Steinkopff.

Drewnowski, A. (2010). The cost of US foods as related to their nutritive value. The American Journal of Clinical Nutrition, 92(5), 1181-1188. PMid:20720258. http://dx.doi.org/10.3945/ajcn.2010.29300. 
Empresa Brasileira de Pesquisa Agropecuária - EMBRAPA. (2013). Catálogo de cultivares de feijão comum. Retrieved from http://snt. sede.embrapa.br

Estrada-Girón, Y., Swanson, B. G., \& Barbosa-Cánovas, G. V. (2005). Advances in the use of high hydrostatic pressure for processing cereal grains and legumes. Trends in Food Science \& Technology, 16(5), 914-203. http://dx.doi.org/10.1016/j.tifs.2004.10.005.

Food and Agriculture Organization - FAO. (2013). FAO statistics, food balance sheets. Retrieved from http://faostat.fao.org.

Hagen, S. R., Frost, B., \& Augustin, J. (1989). Precolumn phenylisothiocyanate derivatization and liquid chromatography of amino acids in food. Journal of Association of Official Analytical Chemists, 72(6), 912916. PMid:2592313.

Han, I. H., Swanson, B. G., \& Baik, B. K. (2007). Protein digestibility of selected legumes treated with ultrasound and high hydrostatic pressure during soaking. Cereal Chemistry, 84(5), 518-521. http:// dx.doi.org/10.1094/CCHEM-84-5-0518.

Horwitz, W., \& Latimer, G. W. (2010). Official methods of analysis of the Association of Official Analytical Chemists. (18th ed.). Gaithersburg: AOAC.

Instituto Adolfo Lutz - IAL. (2008). Métodos físico-químicos para análise de alimentos (4th ed.). São Paulo: Insituto Adolfo Lutz.

Karababa, E. (2006). Physical properties of popcorn kernels. Journal of Food Engineering, 72(1), 100-107. http://dx.doi.org/10.1016/j. jfoodeng.2004.11.028.

Linsberger-Martin, G., Weiglhofer, K., Phuong, T. P. T., \& Berghofer, E. (2013). High hydrostatic pressure influences antinutritional factors and in vitro protein digestibility of split peas and whole white beans. Lebensmittel-Wissenschaft + Technologie, 51(1), 331-336. http:// dx.doi.org/10.1016/j.lwt.2012.11.008.

Lisiewska, Z., Kmiecik, W., \& Slupski, J. (2007). Content of amino acids in raw and frozen broad beans (Vicia faba var. major) seeds at milk maturity stage, depending on the processing method. Food Chemistry, 105(4), 1468-1473. http://dx.doi.org/10.1016/j.foodchem.2007.05.027.

López, A., El-Naggar, T., Dueñas, M., Ortega, T., Estrella, I., Hernández, T., Gómez-Serranillos, M. P., Palomino, O. M., \& Carretero, M. E. (2013). Effect of cooking and germination on phenolic composition and biological properties of dark beans (Phaseolus vulgaris L.). Food Chemistry, 138(1), 547-555. PMid:23265523. http://dx.doi. org/10.1016/j.foodchem.2012.10.107.

Luthria, D. L., \& Pastor-Corrales, M. A. (2006). Phenolic acids content of fifteen dry edible bean (Phaseolus vulgaris L.) varieties. Journal of Food Composition and Analysis, 19(2-3), 205-211. http://dx.doi. org/10.1016/j.jfca.2005.09.003.

Marathe, S. A., Rajalakshmi, V., Jamdar, S. N., \& Sharma, A. (2011). Comparative study on antioxidant activity of different varieties of commonly consumed legumes in India. Food and Chemical Toxicology, 49(9), 2005-2012. PMid:21601612. http://dx.doi.org/10.1016/j. fct.2011.04.039.

Melo, L. C., Costa, J. G. C., Pereira, H. S., Del Peloso, M. J., Wendland, A., Faria, L. C., Nascente, A. S., Díaz, J. L. C., Carvalho, H. W. L., Costa, A. F., Almeida, V. M., Melo, C. L. P., Abreu, Â. F. B., Magaldi, M. C. S., Posse, S. C. P., Souza, B. F. Fo., Souza, J. F., Guimarães, C. M., \& Oliveira, J. P. (2012). Common bean cultivar BRS Ametista with large Carioca grains and disease resistance. Crop Breeding and Applied Biotechnology, 12(4), 293-296. http://dx.doi.org/10.1590/ S1984-70332012000400011.

Park, S. J., Kim, T. W., \& Baik, B. (2010). Relationship between proportion and composition of albumins, and in vitro protein digestibility of raw and cooked pea seeds (Pisum sativum L.). Journal of the Science of Food and Agriculture, 90(10), 1719-1725. PMid:20564440. http:// dx.doi.org/10.1002/jsfa.4007.

Pedrosa, M. M., Cuadrado, C., Burbano, C., Muzquiz, M., Cabellos, B., Olmedilla-Alonso, B., \& Asensio-Vegas, C. (2015). Effects of industrial canning on the proximate composition, bioactive compounds contents and nutritional profile of two Spanish common dry beans (Phaseolus vulgaris L). Food Chemistry, 166(1), 68-75. PMid:25053030. http:// dx.doi.org/10.1016/j.foodchem.2014.05.158.

R Development Core Team. (2012). R: a language and environment for statistical computing. Vienna: R Foundation for Statistical Computing.

Rackis, J. J., Mc Ghee, J. E., Liener, I. E., Kakade, M. L., \& Puski, G. (1974). Problems encountered in measuring Trypsin inhibitor activity of soy flour. Report of collaborative analysis. Cereal Science Today, 19(11), 513-515.

Ranilla, L. G., Genovese, M. I., \& Lajolo, F. M. (2007). Polyphenols and antioxidant capacity of seed coat and cotyledon from Brazilian and Peruvian bean cultivars (Phaseolus vulgaris L.). Journal of Agricultural and Food Chemistry, 55(1), 90-98. PMid:17199318. http://dx.doi. org/10.1021/jf062785j.

Ranilla, L. G., Kwon, Y., Genovese, M. I., Lajolo, F. M., \& Shetty, K. (2010). Effect of thermal treatment on phenolic compounds and functionality linked to type 2 diabetes and hypertension management of Peruvian and Brazilian bean cultivars (Phaseolus Vulgaris L.) using in vitro methods. Journal of Food Biochemistry, 34(2), 329-355. http://dx.doi.org/10.1111/j.1745-4514.2009.00281.x.

Ribeiro, N. D., Londero, P. M. G., Cargnelutti, A. Fo., Jost, E., Poersch, N. L., \& Mallmann, C. A. (2007). Composição de aminoácidos de cultivares de feijão e aplicações para o melhoramento genético. Pesquisa Agropecuária Brasileira, 42(10), 1393-1399. http://dx.doi. org/10.1590/S0100-204X2007001000004.

Sarwar, G. (1997). The protein digestibility-corrected amino acid score method overestimates quality of proteins containing antinutritional factors and of poorly digestible proteins supplemented with limiting amino acids in rats. The Journal of Nutrition, 127(5), 758-764. PMid:9164998.

Sathe, S. K. (2002). Dry bean protein functionality. Critical Reviews in Biotechnology, 22(2), 175-223. PMid:12135167. http://dx.doi. org/10.1080/07388550290789487.

Shimelis, E. A., \& Rakshit, S. K. (2005). Proximate composition and physic-chemical properties of improved dry bean (Phaseolus vulgaris L.) varieties grown in Ethiopia. Lebensmittel-Wissenschaft + Technologie, 38(4), 331-338. http://dx.doi.org/10.1016/j.lwt.2004.07.002.

Shimelis, E. A., \& Rakshit, S. K. (2007). Effect of processing on antinutrients and in vitro protein digestibility of kidney bean (Phaseolus vulgaris L.) varieties grown in East Africa. Food Chemistry, 103(1), 161-172. http://dx.doi.org/10.1016/j.foodchem.2006.08.005.

Sievenpiper, J. L., Kendall, C. W. C., Esfahani, A., Wong, J. M. W., Carleton, A. J., Jiang, H. Y., Bazinet, R. P., Vidgen, E., \& Jenkins, D. J. (2009). Effect of non-oil-seed pulses on glycemic control: a systematic review and meta-analysis of randomised controlled experimental trials in people with and without diabetes. Diabetologia, 52(8), 1479-1495. PMid:19526214. http://dx.doi.org/10.1007/s00125-009-1395-7.

Singleton, V. I., \& Rossi, J. (1965). Colorimetry of total phenolic with phosphomolybdic phosphotungstic acid agents. American Journal of Enology and Viticulture, 16(3), 144-158.

Slupski, J. (2010). Effect of cooking and sterilisation on the composition of amino acids in immature seeds of flageolet bean (Phaseolus vulgaris L.) cultivars. Food Chemistry, 121(4), 1171-1176. http:// dx.doi.org/10.1016/j.foodchem.2010.01.066. 
Thompson, M. D., Thompson, H. J., Brick, M. A., Mcginley, J. N., Jiang, W., Zhu, Z., \& Wolfe, P. (2008). Mechanisms associated with dose-dependent inhibition of rat mammary carcinogenesis by dry bean (Phaseolus vulgaris L.). The Journal of Nutrition, 138(11), 2091-2097. PMid:18936203. http://dx.doi.org/10.3945/ jn.108.094557.

Toledo, N. M., Rocha, L. C., Silva, A. G., \& Canniatti-Brazaca, S. G. (2013). Interaction and digestibility of phaseolin/polyphenol in the common bean. Food Chemistry, 138(2-3), 776-780. PMid:23411175. http://dx.doi.org/10.1016/j.foodchem.2012.11.079.

White, J. A., Hart, R. J., \& Fry, J. C. (1986). An evaluation of the waters Pico-Tag System for the aminoacids analysis of food materials. Journal of Automatic Chemistry, 8(4), 170-177. PMid:18925132. http://dx.doi.org/10.1155/S1463924686000330.
World Health Organization - WHO. (2007). Protein and amino acid requirements in human nutrition (WHO Technical Report Series, 935). Geneva: WHO. Retrieved from http://whqlibdoc.who.int/ trs/WHO_TRS_935_eng.pdf

Wu, X., Beecher, G. R., Holden, J. M., Haytowitz, D. B., Gebhardt, S. E., \& Prior, R. L. (2004). Lipophilic and hydrophilic antioxidant capacities of common foods in the United States. Journal of Agricultural and Food Chemistry, 52(11), 4026-4037. PMid:15186133. http://dx.doi. org/10.1021/jf049696w.

Xu, B., \& Chang, S. K. C. (2009). Total phenolic, phenolic acid, anthocyanin, flavan-3-ol, and flavonol profiles and antioxidant properties of pinto and black beans (Phaseolus vulgaris L.) as affected by thermal processing. Journal of Agricultural and Food Chemistry, 57(11), 4754-4764. PMid:19492791. http://dx.doi.org/10.1021/jf900695s. 